\title{
Antibody-based antiangiogenic and antilymphangiogenic therapies to prevent tumor growth and progression*
}

\author{
Monika Bzowska ${ }^{凶}$, Renata Mężyk-Kopeć, Tomasz Próchnicki, Małgorzata Kulesza, \\ Tomasz Klaus and Joanna Bereta
}

Department of Cell Biochemistry, Faculty of Biochemistry, Biophysics and Biotechnology, Jagiellonian University, Kraków, Poland

\begin{abstract}
Blood and lymphatic vessel formation is an indispensable factor for cancer progression and metastasis. Therefore, various strategies designed to block angiogenesis and lymphangiogenesis are being investigated in the hope to arrest and reverse tumor development. Monoclonal antibodies, owing to their unequalled diversity and specificity, might be applied to selectively inhibit the pathways that cancer cells utilize to build up a network of blood vessels and lymphatics. Among the possible targets of antibody-based therapies are proangiogenic and prolymphangiogenic growth factors from the VEGF family and the receptors to which they bind (VEGFRs). Here, we present molecular mechanisms of angiogenesis and lymphangiogenesis exploited by tumors to progress and metastasise, with examples of antibodybased therapeutic agents directed at interfering with these processes. The expanding knowledge of vascular biology helps to explain some of the problems encountered in such therapies, that arise due to the redundancy in signaling networks controlling the formation of blood and lymphatic vessels, and lead to tumor drug resistance. Nonetheless, combined treatments and treatments focused on newly discovered proangiogenic and prolymphangiogenic factors give hope that more prominent therapeutic effects might be achieved in the future.
\end{abstract}

Key words: monoclonal antibodies, antiangiogenic therapy, antilymphangiogenic therapy, VEGF- A, VEGF-C, VEGF-D

Received: 18 April, 2013; accepted: 28 May, 2013; available on-line: 01 July, 2013

\section{INTRODUCTION}

Cancer is the leading cause of death in developed countries. Although localized tumors are successfully treated by surgery, radiotherapy and other more selective methods, medicine is often helpless in the face of metastatic disease - the most lethal form of cancer. Therefore, enormous efforts are being made to create specific agents with a potential to suppress tumor growth and prevent the processes that cause benign tumors to gain metastatic competence and begin to spread to distant organs. Progression from benign to malignant tumor involves an increase in tumor cell proliferation rate and in the ability to migrate and invade other tissues. Metastatic tumor cells utilize blood and lymph vessels as routes for dissemination. Tumor-derived factors stimulate formation of new blood vessels (angiogenesis) and lymph vessels (lymphangiogenesis), which actively support tumor growth and spreading. Different approaches are applied to inhibit tumor progression. This review will particularly focus on antibody-based therapies inhibiting proangiogenic and prolymphangiogenic signals mediated by endothelial cell growth factors and their receptors. An overview of potential targets for therapeutic monoclonal antibodies in these processes is shown in Table 1. In the future, strategies utilizing such antibodies, alone or combined with other antitumor therapies, may become a method of choice in the treatment of metastatic cancers.

\section{ROLE OF ANGIOGENESIS IN CANCER PROGRESSION}

Angiogenesis is a process involving formation of new blood vessels from preexisting ones. Over forty years ago, Judah Folkman hypothesized that the process of angiogenesis is critical for tumor growth: solid tumors need to develop new blood vasculature to obtain nutrients and oxygen they need to survive and proliferate (Folkman, 1971). Angiogenesis is also an essential component of the metastatic process. Tumor vasculature is a route by which malignant cells exit the primary site to enter general circulation and establish new foci in distant organs. The newly formed blood vessels are immature and leaky, and may not form continuous layer that would prevent intravasation of cancer cells.

Blood vessels are also a dynamic structure connecting tumor environment with the host immune system. Tumor endothelial cells (TECs) interact with the extracellular matrix and stromal tumor cells as well as with

e-mail: monika.bzowska@uj.edu.pl

* Presented at 40th Jubilee Winter School of the Faculty of Biochemistry, Biophysics and Biotechnology of the Jagiellonian University "Contemporary insights into cancer. Risk, perspectives, expectations", February 16-21, 2013, Zakopane, Poland.

Abbreviations: ACT, adoptive cell transfer; ADCC, antibody-dependent cell-mediated cytotoxicity; ANG-2, angiopoietin $2 ; \mathrm{CCL}$, chemokine (C-C motif) ligand; CCR, C-C chemokine receptor; CSCS, cancer stem cells; CXCL, chemokine (C-X-C motif) ligand; dLN, draining lymph node; EGF, epidermal growth factor; EGFR, epidermal growth factor receptor; ErbB, v-erb-a erythroblastic leukemia viral oncogene homolog; Fc, crystallizable fragment; FDA, Food and Drug Administration; FGF, fibroblast growth factor; HB-EGF, heparin-binding EGF-like growth factor; HER2, human epidermal growth factor receptor 2; HGF, hepatocyte growth factor; IFP, interstitial fluid pressure; IL, interleukin; IR, ionizing radiation; KRAS, v-Ki-ras2 Kirsten rat sarcoma viral oncogene homolog; LECs, Iymphatic endothelial cells; Lyve-1, lymphatic vessel endothelial hyaluronan receptor- 1 ; $\mathrm{mAb}$, monoclonal antibody; $\mathrm{mCRC}$, metastatic colorectal cancer; NCAM, neural cell adhesion molecule; NF-kB, nuclear factor $\mathrm{k}$-light-chain-enhancer of activated B cells; Nrp, neuropilin; NSCLC, non-small cell lung carcinoma; PDGF, platelet- derived growth factor; PIGF, placental growth factor; Prox1, Prospero homeobox protein 1; sCFv, single-chain variable fragment; TECs, tumor endothelial cells; TGF, transforming growth factor; TNF, tumor necrosis factor; Tregs, regulatory T cells; VEGF, vascular endothelial growth factor; VEGFR, vascular endothelial growth factor receptor. 
Table 1. Monoclonal antibodies as inhibitors of lymph- and angiogenesis

\begin{tabular}{|c|c|c|c|c|}
\hline Target & Name & Type & Description & Research phase \\
\hline \multicolumn{5}{|l|}{ Antiangiogenic action } \\
\hline VEGF-A & Bevacizumab & $\begin{array}{l}\text { humanized lgG1 } \\
\text { [1] }\end{array}$ & $\begin{array}{l}\text { binds to VEGF-A and inhibits its biological acti- } \\
\text { vity [1] }\end{array}$ & $\begin{array}{l}\text { approved for co- } \\
\text { lorectal cancer, } \\
\text { NSCLC }{ }^{*} \text {, renal cell } \\
\text { carcinoma, gliobla- } \\
\text { stoma }[1]\end{array}$ \\
\hline VEGFR-2 & Ramucirumab & human IgG1 [2] & $\begin{array}{l}\text { blocks VEGF ligand (VEGF-A, VEGF-C and VEGF-D) } \\
\text { binding to VEGFR-2 [2] }\end{array}$ & $\begin{array}{l}\text { Phase } 3 \text { breast } \\
\text { cancer, gastric } \\
\text { cancer, hepatocel- } \\
\text { lular carcinoma, } \\
\text { NSCLC, gastric } \\
\text { cancer, colorectal } \\
\text { cancer [3] }\end{array}$ \\
\hline VEGFR-2 & Tanibirumab & human IgG1 [4] & $\begin{array}{l}\text { blocks VEGF ligand (VEGF-A, VEGF-C and VEGF-D) } \\
\text { binding to VEGFR-2 [4] }\end{array}$ & $\begin{array}{l}\text { preclinical studies, } \\
\text { animal models[4] }\end{array}$ \\
\hline $\begin{array}{l}\text { DIl-4 (Notch Delta- } \\
\text {-like ligand 4) }\end{array}$ & YW152F & humanized Ig [5] & $\begin{array}{l}\text { neutralizes DII-4, induces endothelial cell hyper- } \\
\text { proliferation and formation of defective vessels } \\
\text { [5] when DIl4-Notch signaling is blocked, there } \\
\text { is a decreased tumor growth and a reduction in: } \\
\text { bone marrow-derived pericytes, vascular smooth } \\
\text { muscle cell formation, vessel functionality, lu- } \\
\text { men-bearing vessels [6] }\end{array}$ & $\begin{array}{l}\text { preclinical studies, } \\
\text { animal models }[5,6]\end{array}$ \\
\hline $\begin{array}{l}\text { HK (high molecular } \\
\text { weightkininogen) }\end{array}$ & $\mathrm{C} 11 \mathrm{C} 1$ & murine IgG1 [7] & $\begin{array}{l}\text { inhibits angiogenesis by reducing tumor mi- } \\
\text { crovascular density andblocks binding of HK to } \\
\text { endothelial cells [8] }\end{array}$ & $\begin{array}{l}\text { preclinical, animal } \\
\text { models }[7,8]\end{array}$ \\
\hline $\begin{array}{l}\text { EphB4 (Ephrin type- } \\
\text {-Breceptor 4) }\end{array}$ & $\begin{array}{l}\text { hAb47 and } \\
\text { hAb131 }\end{array}$ & $\begin{array}{l}\text { humanized lgG1 } \\
\text { [9] }\end{array}$ & $\begin{array}{l}\text { hAb131 induces degradation of human EphB4, } \\
\text { inhibits human endothelial tube formation in } \\
\text { vitro and growth of human tumors expressing } \\
\text { EphB4 in vivo hAb47 targets human and murine } \\
\text { EphB4, inhibits angiogenesis and growth of both } \\
\text { EphB4-positive and EphB4-negative tumors in } \\
\text { amouse model [9] }\end{array}$ & $\begin{array}{l}\text { preclinical, animal } \\
\text { models [9] }\end{array}$ \\
\hline $\begin{array}{l}\text { globotriaosylcera- } \\
\text { mide Gb3 }\end{array}$ & $3 \mathrm{E} 2$ & murine IgM [10] & $\begin{array}{l}\text { inhibits: endothelial cell proliferation in vitro, } \\
\text { angiogenesis ex vivo, neuroblastoma develop- } \\
\text { ment and liver metastase spreading in murine } \\
\text { models [10] }\end{array}$ & $\begin{array}{l}\text { preclinical, animal } \\
\text { models }[10]\end{array}$ \\
\hline $\begin{array}{l}\text { YKL-40secreted } \\
\text { glycoprotein }\end{array}$ & $\mathrm{mAY}$ & murine $\lg [11]$ & $\begin{array}{l}\text { inhibits tube formation of microvascular endo- } \\
\text { thelial cells in vitro,prevents YKL-40-induced ac- } \\
\text { tivation of VEGFR-2, restrains tumor growth and } \\
\text { angiogenesis in animal models [11] }\end{array}$ & $\begin{array}{l}\text { preclinical, animal } \\
\text { models [11] }\end{array}$ \\
\hline $\begin{array}{l}\text { Ang-2 (angiopoie- } \\
\text { tin-2) }\end{array}$ & LC06 & human IgG1 [12] & $\begin{array}{l}\text { prevents binding of Ang-2 to its receptor Tie2, } \\
\text { inhibits tumor growth, reduces: intratumoral } \\
\text { microvessel density, tumor vessel branching and } \\
\text { dissemination of tumor cells to the lungs, incre- } \\
\text { ases pericyte coverage [12] coverage [12] }\end{array}$ & $\begin{array}{l}\text { preclinical studies, } \\
\text { animal models [12] }\end{array}$ \\
\hline $\begin{array}{l}\text { Ang-2 (angiopoie- } \\
\text { tin-2) }\end{array}$ & MEDI3617 & human Ig [13] & $\begin{array}{l}\text { prevents Ang-2 bindisng to the Tie2 receptor in } \\
\text { vitro, inhibits angiogenesis and tumor growth in } \\
\text { vivo [13] }\end{array}$ & $\begin{array}{l}\text { preclinical studies, } \\
\text { animal models } \\
{[13,14]}\end{array}$ \\
\hline $\begin{array}{l}\text { HB-EGF(heparin- } \\
\text {-binding EGF-like } \\
\text { growth factor) }\end{array}$ & $Y-142$ & murine Ig [15] & $\begin{array}{l}\text { inhibits sHB-EGF-induced cancer cell proliferation } \\
\text { and sHB-EGF- induced angiogenesis [15] }\end{array}$ & in vitro studies [15] \\
\hline
\end{tabular}

Antiangiogenic and antitumor action

\begin{tabular}{|c|c|c|c|c|}
\hline EGFR & Cetuximab & $\begin{array}{l}\text { chimeric human/ } \\
\text { mouse IgG1[16] }\end{array}$ & $\begin{array}{l}\text { EGFR antagonist [16], may reduce pro-angiogenic } \\
\text { factor secretion by cancer cells [17] cancer cells } \\
\text { [17] }\end{array}$ & $\begin{array}{l}\text { approved for head } \\
\text { and neck cance- } \\
\text { rand colorectal } \\
\text { cancer [16] }\end{array}$ \\
\hline
\end{tabular}


$\begin{array}{lll}\text { EGFR Panitumumab human IgG2 [18] } & \text { human IgG2 competitively inhibits binding of } \\ \text { ligands (eg. EGF, TGFa) to EGFR [18] }\end{array}$

\section{humanized IgG1 mediator of ADCC [20]}

[20]

humanized $\lg G 1$

[21]

\begin{tabular}{|c|c|c|}
\hline HER2 & Pertuzumab & $\begin{array}{l}\text { humanized lgG1 } \\
\text { [21] }\end{array}$ \\
\hline
\end{tabular}

VEGFR-1

Icrucumab

human IgG1 [23]

blocks VEGF-A, VEGF-B and PIGF binding to VEGFR-1; inhibits VEGFR-1 activation in both cancer and non malignant supporting cells that contribute to tumor progression [23] approved for metastatic colorectalcancer [18] Phase 3 (head and neck cancer) Phase 2 (pancreatic cancer) [19]

approved for metastatic breast and gastric cancers [20] approved for breast cancer [22]

Phase 2, colorectal cancer, breast cancer, bladder, urethra, ureter, and renal pelvis carcinoma [24]

Phase 2NSCLC, soft tissue sarcoma, prostate cancer

[27] stromal cells, inhibits tumor and vasculature for mation $[25,26]$

human/mouse chimeric antibody, inhibits endothelial cell proliferation and formation of capillary like structures by endothelial cells, inhibits tumor growth in vivo [28]

Phase $1 \mathrm{~b} / 2 \mathrm{NSCLC}$ [29] mouse lgG4 [28]

specific toward negative regulatory region (NRR) of Notch1; stabilizes NRR quiescence, inhibits

Notch1 anti-NRR1 human $\lg$ G1 [30] cancer cell growth and disrupts tumor angiogenesis, blocks both ligand-dependent and -indepreclinical studies, animal models [30] pendent Notch activation [30]

it does not directly disrupt dimerization of target receptor but leads to its internalization and down-regulation [31] inhibits VEGF secretion and down-regulates migration and proliferation of

preclinical, animal models [32] meric antibody

[31] endothelial cells [32]

Antilymphangiogenesis

\begin{tabular}{|c|c|c|c|c|}
\hline VEGFR-3 & IMC-3C5 & human IgG1 [33] & $\begin{array}{l}\text { blocks VEGF-C and VEGF-D binding to VEGFR-3; } \\
\text { inhibits mitogenic response to mature VEGF-C } \\
\text { [33] }\end{array}$ & Phase 1 [34] \\
\hline VEGF-C & VGX-100 & human lg [35] & $\begin{array}{l}\text { human Ig, blocks VEGF-C binding to VEGFR-2 and } \\
\text { VEGFR-3 [35] }\end{array}$ & Phase 1 [36] \\
\hline ephrinB2 & $\mathrm{B} 11,2 \mathrm{~B} 1$ & $\begin{array}{l}\text { human single- } \\
\text {-chain variable } \\
\text { fragments [37] }\end{array}$ & $\begin{array}{l}\text { suppresses endothelial cell migration and tube } \\
\text { formation in vitro, reduces tumor growth and } \\
\text { inhibits lymph- and angiogenesis in animal mo- } \\
\text { dels [37] }\end{array}$ & $\begin{array}{l}\text { preclinical, animal } \\
\text { models [37] }\end{array}$ \\
\hline VEGF-D & cVE199 & chimeric lgG1 [38] & inhibits VEGF-D binding to VEGFR-3 [38] & $\begin{array}{l}\text { preclinical studies, } \\
\text { animal models[38] }\end{array}$ \\
\hline VEGFR-3 & $2 \mathrm{E} 11$ & - & $\begin{array}{l}\text { inhibits formation of VEGFR-3 homodimers and } \\
\text { VEGFR-3/VEGFR-2 heterodimers but does not } \\
\text { inhibit binding of VEGF-C to VEGFR-3 [39] }\end{array}$ & $\begin{array}{l}\text { preclinical studies, } \\
\text { animal models[39] }\end{array}$ \\
\hline Nrp2 & - & - & $\begin{array}{l}\text { blocks VEGF-C binding to Nrp2 and disrupts lym- } \\
\text { phatic endothelial }\end{array}$ & $\begin{array}{l}\text { preclinical studies, } \\
\text { animal models }\end{array}$ \\
\hline (Neuropilin-2) & & & cell migration $[40]$ & [40] \\
\hline VEGF-C & VC2 & $\begin{array}{l}\text { human single- } \\
\text {-chain variable } \\
\text { fragment }[41]\end{array}$ & $\begin{array}{l}\text { dose-dependently inhibits the binding of VEGF-C } \\
\text { to VEGFR-2 and VEGFR-3 [41] }\end{array}$ & in vitro studies [41] \\
\hline
\end{tabular}


MT1-MMP (MMP-

14, matrix metallo-

protease-14)

VEGFR-2 and

VEGFR-3 blocks the enzymes ability to activate proMMP-2

without interfering with the general proteolytic activity of MT1-MMP, inhibits outgrowth of lymphatic endothelial cells in vitro and lymphatic vessel sprouting ex vivo [42]

directed against VEGFR-2 and VEGFR-3, inhibits activation of both receptors [43] in vitro studies [42]

in vitro studies [43] human diabody constructed of two human single-chain variable fragments [43]

[1] (Roche, Avastin prescribing information, 2013; access on 26.03.2013; www.gene.com/download/pdf/avastin_prescribing.pdf), [2] (Zhu et al., 2003), [3] (ClinicalTrials.gov identifiers: breast cancer NCT00703326, gastric cancer NCT00917384, hepatocellular carcinoma NCT01140347, NSCLC NCT01168973, gastric cancer NCT01170663, colorectal cancer NCT01183780), [4] (Lee, 2011), [5] (Ridgway et al., 2006), [6] (Stewart et al., 2011), [7] (Song et al., 2004), [8] (Khan et al., 2010), [9] (Krasnoperov et al., 2010), [10] (Desselle et al., 2012), [11] (Faibish et al., 2011), [12] (Thomas et al., 2013), [13] (Leow et al., 2012), [14] (Holopainen et al., 2012), [15] (Sato et al., 2012), [16] (Merc, Erbitux prescribing information, 2012), [17] (Perrotte et al., 1999), [18] (Amgen, Panitumumab prescribing information, 2013; access on 26.03.2013; www.pi.amgen.com/united_states/vectibix/vectibix_pi.pdf), [19] (ClinicalTrials.gov identifiers: head and neck cancer NCT00460265, pancreatic cancer NCT01175733), [20] (Roche, Herceptin prescribing information, 2010; access on 26.03.2013; www.herceptin.com/pdf/herceptin-prescribing.pdf), [21] (El-Sahwi, 2010), [22] (Roche, Perjeta prescribing information, 2012; access on 26.03.2013; www.accessdata.fda.gov/drugsatfda_docs/label/2012/125409lbl.pdf), [23] (Wu et al., 2006), [24] (ClinicalTrials. gov identifiers: colorectal cancer NCT01111604, breast cancer NCT01234402, bladder, urethra, ureter, and renal pelvis carcinoma NCT01282463), [25] (Shah et al., 2010), [26] (Gerber et al., 2012), [27] (ClinicalTrials.gov identifiers: NSCLC NCT00918203,soft tissue sarcoma NCT00918203, prostate cancer NCT01204710), [28] (Bhaskar et al., 2008) , [29] (Besse et al., 2013), [30] (Wu et al., 2010), [31] (Zhou et al., 2011), [32] (Shen et al., 2011), [33] (Persaud et al., 2004), [34] (ClinicalTrials.gov identifier: NCT01288989), [35] (Hajrasouliha et al., 2012), [36] (ClinicalTrials.gov identifier: NCT01514123), [37] (Abengozar et al., 2012), [38] (Kashima et al., 2012), [39] (Tvorogov et al., 2010), [40] (Caunt et al., 2008), [41] (Rinderknecht et al., 2010), [42] (Ingvarsen et al., 2013), [43] (Jimenez et al., 2005).

immune cells (Berezhnaya, 2010). They also control leukocyte recruitment and may contribute to the immune escape of tumors (Bussolati et al., 2003; Chouaib et al., 2010). For many years, it was thought that biological properties of TECs are identical or similar to those of endothelial cells from healthy tissue. However, recent studies on isolated TECs revised this hypothesis. TECs are described as "chronically activated or inflamed" (Dudley, 2012). Tumor cells produce many factors, such as TNF, which stimulate expression of adhesion molecules Thy-1, E- selectin, NCAM (Bussolati et al., 2003) on the endothelial cells. Activated endothelium recruits proinflammatory cells, in particular macrophages, which might contribute to angiogenesis and tumor progression.

\section{The role of VEGF/VEGFR signaling in tumor development and metastasis}

New blood vessel formation is a complex process regulated by numerous proangiogenic modulators, among which the vascular endothelial growth factor-A (further referred to as VEGF) seems to play a predominant role. VEGF, also known as vascular permeability factor, is a key angiogenic factor that regulates both normal and tumor angiogenesis (Ferrara \& Gerber, 2001). It belongs to the VEGF family of ligands that consists of seven members: VEGF-A, VEGF-B, VEGF-C, VEGF-D, VEGF$\mathrm{E}, \mathrm{VEGF}-\mathrm{F}$ and the placental growth factor (PlGF). These ligands exert their biological activity upon binding to tyrosine kinase receptors VEGFRs (VEGFR-1, VEGFR-2 and VEGFR-3). Activation of VEGFR-1 and VEGFR-2 signaling leads to migration of hematopoietic cells and growth, migration and survival of vascular endothelial cells (Ferrara et al., 2003; Ferrara, 2004).

VEGF is overexpressed in tumors compared to normal tissues. It is secreted not only by tumor cells but also by tumor-associated stromal cells in response to hypoxic conditions in pathologically expanding tumor tissue. VEGF induces angiogenesis by activating signaling through VEGFR in the blood vessels surrounding the tumor (Fukumura et al., 1998).

Expression of VEGF in solid tumors stimulates new blood vessel formation, which is crucial for the contin- ued tumor growth as well as for metastasis. Additionally, expression of VEGFR-2, a major receptor involved in malignant angiogenesis, is upregulated several-fold in tumor vascular endothelial cells (Plate et al., 1994). VEGFR-2 is also expressed on immune cells and, after its activation by VEGF, plays an important role as a factor suppressing anti-tumor immunity (Ohm \& Carbone, 2001; Suzuki et al., 2010). Many studies demonstrated that a high level of plasma VEGF correlated with disease progression, resistance to chemotherapy and poor prognosis for cancer patients (Lee et al., 2000; Poon et al., 2001).

VEGF is a critical survival factor for tumor endothelial cells; therefore a constant supply of VEGF to the tumor is essential not only for the development of new tumor vasculature but also for the maintenance of blood vessels that already exist within the tumor. In the light of these data it has been proposed that the VEGF/ VEGFR axis could be a potential target for developing antiangiogenic and anticancer therapy. However, it is clear that antiangiogenic therapy should not only focus on tumor endothelium; other cells participating in new blood vessel formation like pericytes, fibroblasts, stromal cells and bone marrow-derived endothelial progenitor cells also seem to constitute valuable targets. It should also be noted that a growing body of evidence indicates the significant role not only of blood vessels but also of the lymphatic vessel system in tumor progression. Tumor cells infiltrating the draining lymph nodes (dLNs) are regarded as an important diagnostic factor indicative of the stage and malignancy of the disease.

\section{ROLE OF LYMPHANGIOGENESIS IN CANCER PROGRESSION}

The lymphatic vessel system is composed of blindended initial lymphatics, precollecting vessels, collecting vessels and the thoracic duct. One of its major physiological roles is to maintain tissue fluid balance by draining protein-rich fluid from the interstitial space and driving it back to the blood circulation. Lymphatic vessels are also involved in the immune response. They are re- 
sponsible for the transport of antigens and constitute a route for antigen-presenting dendritic cells leading from peripheral tissues to the dLNs (Lund \& Swartz, 2010). Tumor lymphatic vessels are also engaged in the transport of tumor-derived growth factors and other proteins to the local lymph nodes. There they can exert immunosuppressive or immunomodulatory effects, facilitating evasion of tumor cells from the immune surveillance (Lund et al., 2012).

Formation of the lymph vessel system takes place during embryonic development. In adults, the growth of new lymphatic vessels occurs during inflammation and wound healing. Excessive lymphangiogenesis is observed in chronic inflammation, autoimmune disorders, graft rejection and, as it will be discussed in this review, in tumor progression (Alitalo, 2011).

Although the importance of the lymphatic system for tumor development and spreading has been generally accepted for many years, deeper insight into the biology of the lymphatics has long been hampered due to the lack of defined lineage-specific markers.

The discovery of such markers for the lymphatic endothelial cells (LECs): Lyve-1 (Banerji et al., 1999), Prox1 (Wigle \& Oliver, 1999), and podoplanin (Breiteneder-Geleff $e t$ al., 1999), enabled significant progress in understanding the mechanisms responsible for lymphatic-dependent metastasis. It is now well documented that lymphangiogenesis induced by the growing tumor allows cancer cells to metastasise to the dLNs (Christiansen \& Detmar, 2011). Thus, lymphatic vessels are now considered one of the major routes for tumor cell spreading from primary sites to lymph nodes and, further, to distant tissues.

\section{Prolymphangiogenic growth factors}

Data from in vitro as well as from in vivo experiments point at VEGF-C and VEGF-D as major growth factors driving tumor-dependent lymphangiogenesis through activation of VEGFR-3 and its coreceptor neuropilin 2 (Nrp2) (Makinen et al., 2001; Mandriota et al., 2001; Kar- panen et al., 2006; Xu et al., 2010; Chen, et al., 2012). Since VEGF-C and VEGF-D can also activate VEGFR-2, they are considered proangiogenic factors as well (Leppanen et al., 2010). VEGF-C and VEGF-D produced by tumor cells along with tumor-infiltrating macrophages stimulate LEC proliferation, survival, and migration (Makinen et al., 2001; Schoppmann et al., 2002; Otrock et al., 2007). VEGF-C has also been shown to stimulate LECs to express CCL21 and CCL19, chemokines which attract CCR7-positive tumor cells to the lymph vessels. As a result of this observation, LECs are now considered active players in tumor metastasis (Issa et al., 2009). The roles attributed to VEGF-C regarding tumor development are presented in Fig. 1.

The results of in vivo experiments are even more convincing. VEGF-C significantly increased intratumoral lymphangiogenesis in a breast cancer model and the extent of this process correlated with the dLN and lung metastasis (Skobe et al., 2001). In B16 melanoma model, overexpression of VEGF-C resulted in increased lymphangiogenesis around the tumor and metastasis to the dLNs (Lund et al., 2012). Similar correlation between VEGF-D-stimulated lymphangiogenesis and dLN metastasis was also reported (Stacker et al., 2001). These observations are in accordance with the results of in vivo experiments in which the VEGF-C/VEGFR-3 axis has been blocked. The silencing of VEGF-C and/or VEGFR-3 expression resulted in decreased metastasis in mouse models of breast-, bladder- and lung cancers (Chen et al., 2005; Wang et al., 2010; Feng et al., 2011).

Recent data showed that the tumor-derived lymphangiogenic growth factors are transported through the lymphatics and lead to expansion of the lymphatic network in the draining lymph nodes before the actual metastasis occurs, thereby preparing a premetastatic niche, enabling the seeding of tumor cells to the dLN (Liersch et al., 2012).

In addition to animal models, there are an impressive number of studies on patients suffering from gastric carcinoma, melanoma and breast cancer, showing a close

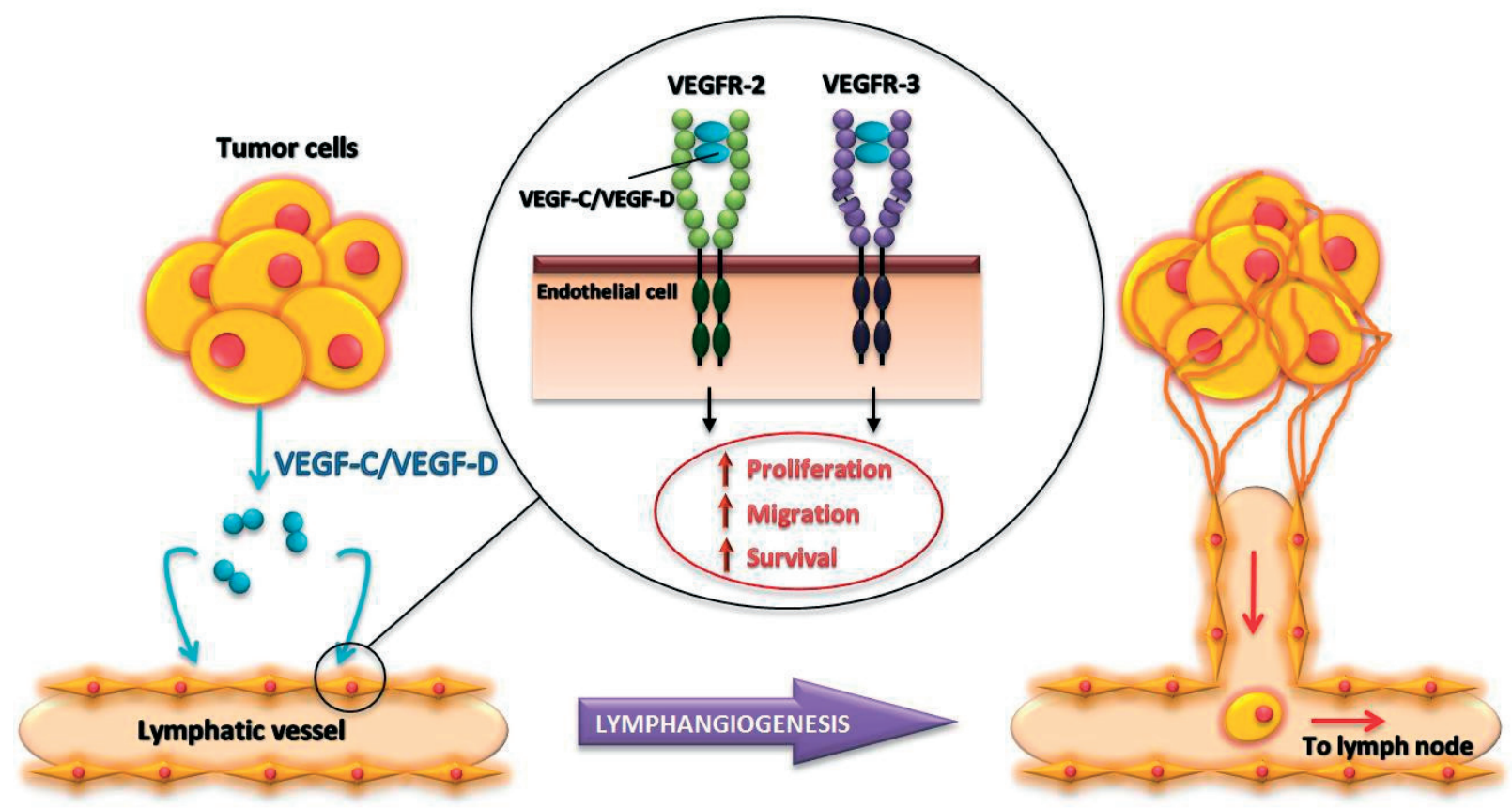

Figure 1.The role of VEGF-C in cancer metastasis is the promotion of tumor-associated lymphangiogensis. Based on Alitalo et al., 2005. 
correlation between the serum level of VEGF-C, the density of lymphatic vessels and the incidence of lymph node metastases (Gao et al., 2009; Cianfarani et al., 2012; Ding et al., 2012). In addition to VEGF-C and VEGF$\mathrm{D}$, also other factors, such as VEGF-A, FGF, ANG-2, and HGF may control the process of lymphangiogenesis and lymphatic metastasis (Achen \& Stacker, 2006).

Today, it is clear that both angiogenesis and lymphangiogenesis may serve as excellent targets for cancer therapies. The antiangiogenic therapies are already evaluated in medical procedures while antilymphangiogenic therapies are still at the stage of preclinical and clinical trials.

\section{ANTIBODY-BASED THERAPIES TO INHIBIT ANGIOGENESIS}

Several preclinical studies demonstrated that monoclonal antibodies specific for VEGF completely suppressed tumor angiogenesis and inhibited the growth of humanderived tumor cell lines injected into nude mice. These results strongly suggested that VEGF inhibitors blocked both angiogenesis and tumor growth (Kim et al., 1993; Warren et al., 1995; Borgstrom et al., 1998) and led to development of therapeutic anti-VEGF monoclonal antibodies.

\section{Monoclonal antibody neutralizing VEGF}

Bevacizumab (produced by Genentech/Roche and distributed under the name Avastin) is a humanized monoclonal antibody that specifically recognizes, removes from the circulation and suppresses biological activity of human VEGF. In 2004 bevacizumab was approved by FDA for treatment of metastatic colorectal cancer (mCRC) and thus became the first antiangiogenic drug accepted for cancer therapy. Bevacizumab is generally well tolerated by patients but sometimes it has specific adverse effects, most commonly hypertension, proteinuria, bleeding, wound healing complications, and thromboembolism (Fox et al., 2007).

After the unsatisfactory results of the initial trials with bevacizumab as a single agent (Giantonio et al., 2007) it is now most commonly used in combination with cytotoxic therapy for treatment of mCRC, non-small cell lung cancer, and renal cell cancer (Roche, Avastin prescribing information, 2013 ${ }^{1}$, while the use of bevacizumab as a single agent is limited to the palliative treatment of patients suffering from glioblastoma multiforme (Agha et al., 2010, Chamberlain, 2011). In combination with chemotherapy, bevacizumab prolonged progression-free survival compared to chemotherapy alone, and showed meaningful clinical benefits in patients with different tumor types (Kabbinavar et al., 2003; Hurwitz et al., 2004; Miller et al., 2007). In 2008 FDA approved bevacizumab for treatment of patients with HER2-negative metastatic breast $\mathrm{t}^{1}$ cancer on the basis of previous clinical studies that demonstrated an increase in progression-free survival of patients submitted to combined therapy of bevacizumab and paclitaxel (O'Shaughnessy, 2010; Ocana et al., 2011). However, further clinical trials showed that combination of bevacizumab with cytotoxic agents did not lead to any increase in overall survival of patients with breast cancer and, additionally, this therapy was associated with a high risk of severe life threatening events, the reasons of which are discussed below. The synergistic effect of bevacizumab and chemotherapeutic agents observed in some types of tumors is probably associated with normalization of the tumor vasculature by inhibition of VEGF/VEGFR signaling. Elevated level of VEGF in tumors leads to disorganization and lack of typical hierarchy of tumor blood vessels. It is also reported that high permeability of the tumor vasculature and high interstitial fluid pressure (IFP) in tumors results from a high VEGF level in the tumor microenvironment. It is believed that VEGF inhibition by bevacizumab causes a decrease in IFP and thus improves transfer of chemotherapeutic agents into the tumor (Jain \& Carmeliet, 2001; Gerber \& Ferrara, 2005).

The efficiency of bevacizumab in combined therapies is constantly under investigation. Preclinical studies demonstrated that bevacizumab might act as a biological enhancer of radiation therapy. Experiments performed by Gorski and colleagues showed that exposure to ionizing radiation (IR) strongly induced VEGF expression in the tumor (Gorski et al., 1999), which is regarded as an important element of tumor resistance to radiation therapy. Blockade of tumor angiogenesis with bevacizumab could improve the therapeutic efficacy of IR. This strategy, however, requires verification in clinical trials (Kim et al., 2013).

Apart from its role in angiogenesis, VEGF is also an important immunomodulatory factor that might have a suppressive effect on antitumor immune response. In this respect, VEGF induces the activity of regulatory $\mathrm{T}$ cells (Tregs) (Li et al., 2006) and strongly inhibits differentiation of hematopoietic progenitor $\mathrm{CD}_{3}{ }^{+}$cells into conventional dendritic cells by inactivating $\mathrm{NF}-x \mathrm{~B}$ transcription factor through VEGFR-1 (Gabrilovich et al., 1998; Oyama et al., 1998). Since Tregs can promote immune suppression and the dendritic cells play an important role in host anti-tumor response, high levels of VEGF could contribute to tumor immune escape. Therefore, inhibition of the VEGF/VEGFR-1 signaling pathway with bevacizumab could be a strategy to improve dendritic cell maturation and enhance host immune response to tumor (Osada et al., 2008). Adoptive cell transfer (ACT) immunotherapy is a new approach involving transfusion of different leukocyte subsets into patients in order to eradicate tumor cells with the use of immune mechanisms (June, 2007). Based on the fact that the ACT strongly depends on the extravasation of the leukocytes from tumor vessels into the tumor stroma, it can be supposed that the immunological cells administered to patients during ACT treatment would be most effective in interaction with endothelial cells in normalized vessels. Therefore, it is proposed that treatment with anti-VEGF antibodies prior to the ACT procedure may have a beneficial effect on the success of the therapy. Such an approach was investigated on the model of metastatic melanoma. As shown in studies on animal models, mAb that blocks VEGF can also normalize tumor vasculature, upregulate endothelial adhesion molecules in tumor vessels, and increase the number of tumor-infiltrating leukocytes (Mulligan et al., 2009; Shrimali et al., 2010). The efficacy of ACT combined with anti-VEGF has recently been tested in the therapy of human cancer (Kandalaft et al., 2013).

High expectations associated with bevacizumab after the positive results of preclinical studies were not fulfilled. The best clinical effects of bevacizumab are obtained in combination therapy of mCRC. Nevertheless, 
even in these cases, bevacizumab is not capable of arresting the progression of the disease and the possible long-term effect of the inhibition of VEGF is the development of therapy resistance mechanisms in the tumor. However, it should be emphasized that bevacizumab is recommended for patients with advanced and metastatic cancers and it cannot be excluded that its effectiveness could be greater if the therapeutic was applied at less advanced stages of the disease.

\section{Monoclonal antibodies blocking VEGFR}

Another strategy for suppression of VEGF/VEGFR signaling involves monoclonal antibodies targeting receptors for VEGF. Animal studies with a rat MF1/IMC$18 \mathrm{~F} 1 \mathrm{mAb}$ (developed by ImClone Systems) specific to VEGFR-1 demonstrated that suppression of this receptor effectively blocked tumor angiogenesis and metastasis (Luttun et al., 2002). Later, the same company generated a fully human mAb (IMC-18F1) specific to VEGFR-1, the antiangiogenic and tumoricidal activity of which was tested both in vitro and in vivo on human breast carcinoma models. Results of these studies showed that IMC18F1 inhibited VEGF, VEGF-B and PlGF binding to VEGFR-1, thus suppressing tumor growth (Wu et al., 2006). The antiangiogenic and tumor-suppressing activity of IMC-18F1 is being evaluated in an ongoing Phase 2 clinical trial. Encouraging results of studies on VEGFR-1 inhibitor inspired ImClone Systems to develop $\mathrm{mAb}$ specific to VEGFR-2: IMC-1121B (ramucirumab) is a human $\mathrm{mAb}$ which binds to the extracellular domain of VEGFR-2. Anticancer efficacy of ramucirumab was verified in completed Phase 1 clinical trials, which were carried out on patients with melanoma, gastric adenocarcinoma, uterine leiomyosarcoma and renal cancer. At present, ramucirumab is tested in Phase 2 and 3 clinical trials as a single agent or combined with paclitaxel, docetaxel, carboplatin, or other cytotoxic drugs (Zhu et al., 2003).

In October 2012 Eli Lilly, Inc. (ImClone Systems) announced the results of the REGARD trial, which was one of the two ramucirumab Phase 3 studies on advanced gastric cancer. It showed that ramucirumab used as a single agent statistically improved overall survival and prolonged progression-free survival of patients with advanced gastric cancer. The ongoing Phase 3 RAINBOW study is carried out to verify clinical activity of ramucirumab combined with paclitaxel in metastatic gastric cancer $^{2}$. It is noteworthy that AVAGAST, a similar study in which bevacizumab was tested in combination with first-line chemotherapy on gastric cancer, did not meet its primary endpoint of extending overall survival in patients. The still unanswered question is whether the therapy with ramucirumab could show actual clinical benefit in cancer types where bevacizumab was not successful (Ohtsu et al., 2011).

\section{Tumor resistance to antiangiogenic therapy targeting VEGF/VEGFR}

Resistance to therapy is a major clinical problem that strongly affects successful treatment of patients with cancers (Lee et al., 2012). Antiangiogenic therapy was developed as a novel anticancer strategy in the hope to avoid the problems of tumor resistance because it targets stable endothelial cells instead of unstable tumor cells
(Kerbel, 1991; Boehm et al., 1997). Since clinical studies with bevacizumab revealed limited therapeutic efficacy of this drug, at least two important questions were raised: firstly, whether the tumor could develop resistance to antiangiogenic agents; and secondly, if such resistance might be considered as a major reason for the failure of this therapy. Recent data indicate that tumor progression after antiangiogenic treatment can be the result of different mechanisms of adaptation depending on tumor type and microenvironment, which involve both tumor cells and stromal components (for review see Grepin \& Pages, 2010; Loges et al., 2010).

\section{Selection of more invasive tumor cells ${ }^{2}$}

Several months after FDA revoked the approval for bevacizumab for treatment of metastatic breast cancer, Conley and colleagues from the University of Michigan Department of Internal Medicine published results of studies performed in order to elucidate potential reasons of the limited efficacy of antiangiogenic drugs. They hypothesized that the highly metastatic cancer stem cells (CSCs) play a crucial role in the acceleration of tumor growth, observed very often after antiangiogenic treatments (Burstein et al., 2008). Using mouse model of human breast cancer, they demonstrated that administration of antiangiogenic agents such as bevacizumab or sunitinib (receptor tyrosine kinase inhibitor) leads to the generation of hypoxia within the tumor tissue. This activates hypoxia-inducible factor $1 \alpha$, which increases the number of CSCs in the tumor. Accelerated regrowth of breast tumors results from an increase in the aggressive breast CSCs population (Conley et al., 2012). Authors of the abovementioned studies claim that a combined therapy targeting both the tumor vasculature and CSCs might overcome tumor resistance to antiangiogenic agents.

\section{Angiogenic redundancy}

The VEGF/VEGFR signaling pathway plays a predominant role in tumor angiogenesis. However, it is clear that this process is also regulated by many other factors. When VEGF-dependent angiogenesis is blocked by agents such as bevacizumab or sunitinib, the tumor adaptation involves upregulation of other proangiogenic stimulators including VEGF-B, PlGF, TNF, fibroblast growth factors (FGFs), plateled-derived growth factor (PDGF), angiopoietin 1 and 2, ephrins, TGF- $\alpha$, TGF- $\beta$, or HB-EGF (Casanovas et al., 2005; Fischer et al., 2008; You \& McDonald, 2008; Acevedo et al., 2009; Lieu et al., 2011). It is thought that targeting more than one angiogenic pathway at the same time could prevent angiogenic redundancy and increase anticancer activity of antiangiogenic therapies (Gossage \& Eisen, 2010).

Many studies indicate that EGFR signaling strongly contributes to tumor angiogenesis (Ellis, 2004). The epidermal growth factor receptor (EGFR) family consists of four members (EGFR, ErbB2, ErbB3, and ErbB4; further referred to as EGFRs) that are activated upon binding of the EGF- family ligands (EGF, TGF- $\alpha$, HB-EGF, amphiregulin, neuregulin). EGFRs, as well as EGF-family ligands, are overexpressed in numerous solid tumor types (Laskin \& Sandler, 2004; Laskin \& Sandler, 2004) and in tumor endothelium (Amin et al., 2006; Amin et al., 2008). Activation of EGFRs by their ligands is gener-

\footnotetext{
${ }^{2}$ [online] access on 26.03.2013; www.targetedhc.com/articles/Ramucirumab-Achieves-Primary-Endpoint-as-Single-Agent-in-Metastatic-Gastric-Cancer
} 


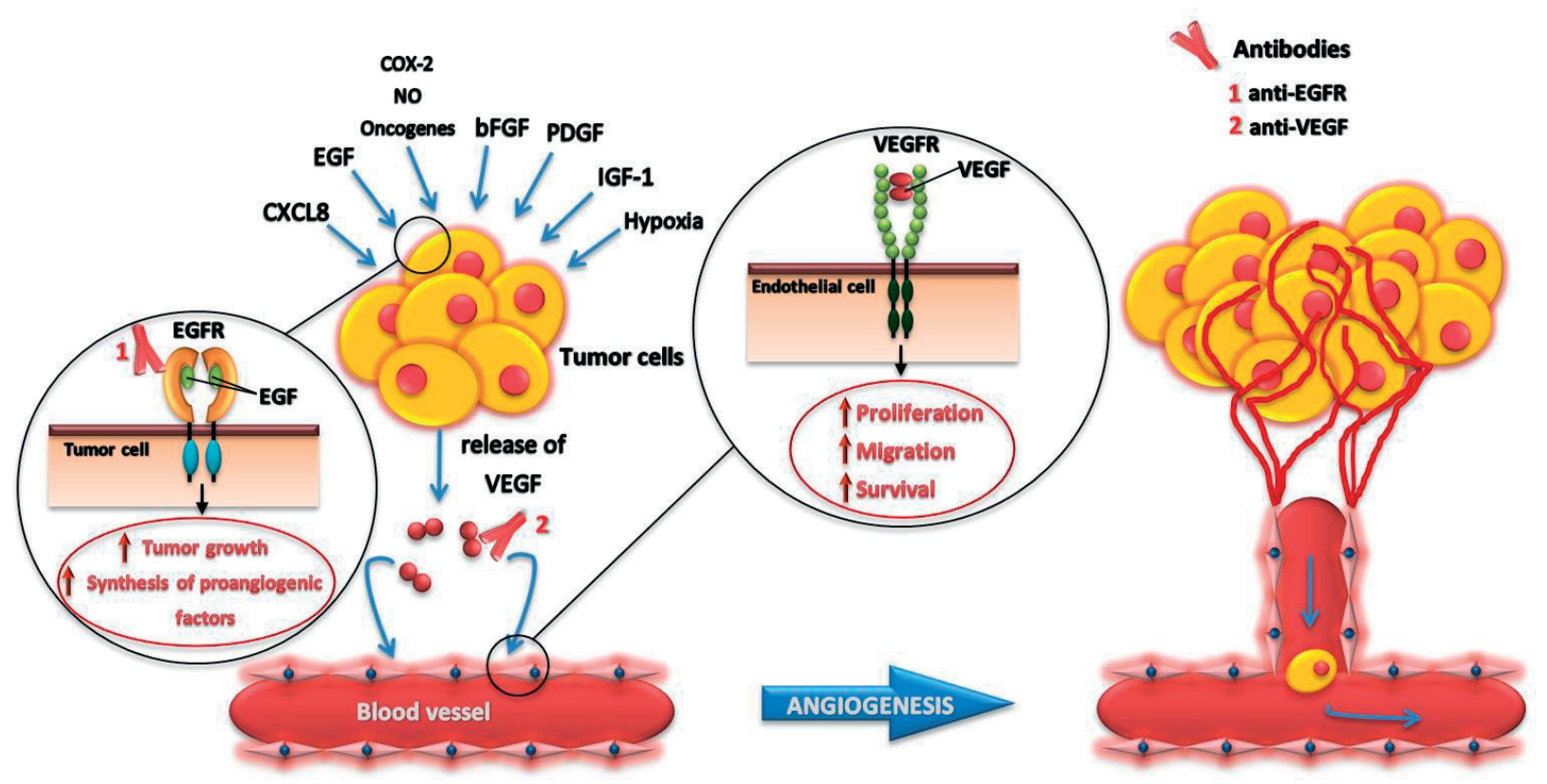

Figure 2. The interconnection of EGFR and VEGF pathways with respect to angiogenesis.

Simultaneous blockade of these signaling pathways by monoclonal antibodies was tested to target tumors in therapies. Based on Alitalo et al., 2005.

ally accepted as crucial for tumor progression and metastasis because it stimulates multiple signaling pathways leading to increased cell survival, proliferation, and motility (Yarden, 2001). EGFRs signaling regulates the expression of several key proangiogenic factors, including VEGF, chemokine (C-X-C motif) ligand 8 (CXCL8), and basic fibroblast growth factor (bFGF) (Goldman et al., 1993), as summarized in Fig. 2. In preclinical models, suppression of EGFR signaling resulted in downregulation of proangiogenic factors and decrease in tumor blood vessel density as well as metastasis (Ellis, 2004). It has been recently demonstrated that EGFR is activated on stromal cells in bevacizumab-resistant tumors and that the combined therapy with bevacizumab and erlotinib (small-molecule EGFR tyrosine kinase inhibitor) may delay tumor adaptation to antiangiogenic treatment (Cascone et al., 2011).

Presently, two therapeutic monoclonal antibodies specific to EGFR, cetuximab and panitumumab, are approved for treatment in patients with cancer. Cetuximab (distributed as Erbitux, marketed by Merck Serono) is a human-murine chimeric monoclonal antibody that binds to the extracellular domain of human EGFR hindering its activation. It was approved by FDA in 2004 for treatment of patients with EGFR-expressing, KRAS wildtype $\mathrm{mCRC}$ as well as head and neck cancer (Jonker et al., 2007; Bonner et al., 2010).

In vitro and in vivo studies showed that the anticancer activity of cetuximab probably results from direct suppression of EGFR signaling and involves inhibition of cell cycle progression (Wu et al., 1995), angiogenesis and invasion (Perrotte et al., 1999). The Fc fragment of cetuximab (an IgG1 class antibody) may also trigger immune mechanisms such as antibody-dependent cell-mediated cytotoxicity (ADCC) and complement-dependent cytolysis (CDC). Intravenous administration of cetuximab may result, in some patients, in a severe infusion reaction due to the presence of mouse protein sequences (Patel \& Goldberg, 2006). However, anti-EGFR therapy can be also conducted with a fully human antibody, panitumumab (distributed as Vectibix, marketed by Amgen) (Heun \& Holen, 2007; Keating, 2010). Both these anti-EGFR mAbs have proven their clinical usefulness. Nevertheless, tumor drug resistance remains a serious clinical problem that strongly affects their therapeutic efficacy. The mechanism of resistance to anti-EGFR therapy is not yet understood but some data indicate a potential role of VEGF in that process. Viloria-Petit et al. demonstrated that tumors that developed resistance to cetuximab overexpressed VEGF (Viloria-Petit et al., 2001). Other studies showed increased expression of VEGFR-1 and VEGFR-2 on resistant tumor cells and also confirmed an important role of the VEGF/ VEGFR signaling pathway in the development of resistance to the anti-EGFR antibody (Ciardiello et al., 2004; Bianco et al., 2008). Interference and cross-talk between the VEGFR and EGFR signaling axes led to the assumption that they might constitute a very attractive target for combined therapy. Preclinical studies confirmed that simultaneous suppression of EGFR signaling by a monoclonal antibody and inhibition of VEGF secretion by VEGF antisense oligonucleotides prolonged tumor growth inhibition as compared to controls (monoclonal anti-EGFR antibody alone, or VEGF antisense oligonucleotide alone) (Ciardiello et al., 2000). The results of the BOND2 trial, which tested the anticancer activity of cetuximab combined with bevacizumab in patients with advanced mCRC, were also promising (Saltz et al., 2007). Alas, further studies did not confirm clinical benefits of such a strategy: results of the CAIRO2 study (combination of bevacizumab and cetuximab with chemotherapy) and the PACCE study (combination of bevacizumab and panitumumab with chemotherapy) revealed that the combined anti-VEGF and anti-EGFR monoclonal antibody- based treatment merged with chemotherapy resulted in a statistically decreased progression-free survival in patients with advanced colorectal cancer (Hecht et al., 2009; Tol et al., 2009).

To summarize, despite significant progress in understanding the mechanism of angiogenesis and in pro- 
duction of different types of antibodies to inhibit this process, success in overcoming angiogenesis-dependent tumor growth and metastasis is a still unattained goal. In the context of tumor metastasis, merging antiangiogenic therapies with strategies targeting another route of cancer dissemination, the lymphatic vessel system, might have favorable outcomes. Inhibition of tumor metastasis through blood vessels, while the lymphatic vessel system is still unimpaired by treatment, may not be enough to prevent cancer dissemination.

\section{ANTIBODY-BASED THERAPIES TO INHIBIT LYMPHANGIOGENESIS}

\section{Monoclonal antibodies blocking VEGFR-3}

Since VEGF-C and VEGF-D, and their receptors were the first identified factors that drive tumor lymphangiogenesis, the first neutralizing antibodies were directed towards the VEGF-C/VEGF-D/VEGFR-3 signaling axis components. Pytowski et al. produced mF4-31C1, an anti-VEGFR-3 mAb that antagonized the binding of VEGF-C to this receptor. Administered into mice, this $\mathrm{mAb}$ potently inhibited formation of new lymphatic vessels, without affecting the preexisting ones (Pytowski et al., 2005). Another anti-VEGFR-3 mAb, hF43C5, was produced by Persaud et al. This $\mathrm{mAb}$ binds to VEGFR-3 with high affinity and blocks its interaction with VEGF-C (Persaud et al., 2004). Subsequently, Jimenez et al. produced a more sophisticated antibody - a bispecific antibody (diabody), which simultaneously binds to VEGFR-2 and VEGFR-3, and blocks their interaction with VEGF and VEGF-C. In in vitro studies, this diabody inhibited both VEGF- and VEGF-C-stimulated migration of endothelial cells. Diabodies directed against two different tumor-associated targets, are supposed to have enhanced therapeutic activity (Jimenez et al., 2005).

All mAbs described above inhibit ligand binding to VEGFR-3. The outcome of this inhibition depends on $\mathrm{mAb}$ affinity and on the ratio of concentrations of the VEGF family ligand and the antibody, since the antibody competes with the ligand for receptor binding. High ligand-to-antibody ratio could decrease the blocking efficacy of $\mathrm{mAb}$ directed against ligand binding sites in the receptor. To overcome this problem, Tvorogov et al. (2010) produced an anti-VEGFR-3 mAb that blocks dimerization of the receptor and thus abrogates signal generation in a ligand concentration-independent manner. Since elevated inhibitory activity and better therapeutic outcome is expected from therapies utilizing combinations of antibodies, this group combined an anti-dimerization antibody with an antibody which blocks ligand binding. In this configuration the inhibitory effect on sprouting, migration and in vivo tube formation by microvascular endothelial cells was more pronounced (Tvorogov et al., 2010).

Anti-VEGFR-3 therapies are of great importance due to the fact that, in addition to expression on lymphatic vessels, VEGFR-3 is also expressed on tumor microvasculature in angiogenic sprouts. Antibodies which block the ligand binding site of VEGFR-3 significantly reduce blood vessel density and sprouting. Thus, anti-VEGFR-3
mAbs not only reduce lymphangiogenesis but might also be beneficial in antiangiogenic therapies, especially in combination with anti-VEGFR-2 mAbs (Tammela et al., 2008).

To our knowledge, despite encouraging in vitro and in vivo results, only one anti-VEGFR-3 antibody, IMC3C5, produced by ImClone LLC, has entered Phase 1 clinical trials. The results of these studies are supposed to be completed by the end of 2013 (ClinicalTrials.gov identifier: NTC01288989). IMC-3C5 combined with classical chemotherapy demonstrated significant inhibition of tumor growth in animal models of lung and head and neck cancers. The inhibitory effect of combined treatment surpasses that of either agent alone. Thus, IMC3C5 is supposed to improve today's chemotherapy treatment $^{3}$.

\section{Monoclonal antibodies neutralizing VEGF-C and VEGF-D}

Neutralization of VEGF-C and VEGF-D is another approach to inhibit lymphangiogenesis through interference with the VEGF-C/VEGF-D/VEGFR-3 signaling axis. As the mature form of VEGF-C can signal through both VEGFR-3 and VEGFR-2 (Plate, 2001), inhibition of VEGF-C may have an impact not only on lymphangiogenesis but on angiogenesis as well. One of the antibodies produced to achieve this goal, an $\mathrm{scF}_{\mathrm{v}}$ format anti-VEGF-C antibody binding to an epitope that is important for receptor binding, was generated by Rinderknecht et al. (Rinderknecht et al., 2010). Two years later, Kashima et al. produced an anti-VEGF-D antibody (cVE199) inhibiting the binding of VEGF-D to VEGFR-3. The inhibitory activity of this antibody was confirmed in vitro and in vivo on a model of neuroblastoma. cVE199 significantly inhibits both lymphangiogenesis and lymphatic metastasis (Kashima et al., 2012).

Until now, only one anti-VEGF-C antibody has been translated from preclinical studies into a clinical development stage: VGX-100 (produced by Circadian Technologies Limited) entered Phase 1 clinical trials ${ }^{4}$ in 2012. VGX-100 combined with bevacizumab and/or chemotherapy significantly decreased the growth of tumors in the animal models of glioblastoma, prostate cancer and pancreatic cancer.

\section{Antibodies binding newly recognized prolymphangiogenic factors ${ }^{3,4}$}

With meaningful progress in the field of lymphangiogenesis, more factors stimulating this process have been identified. Since in vitro and in vivo data confirmed their contribution to lymphatic vessel metastasis, they are now considered potential therapeutic targets. One such newly identified prolymphangiogenic factor is ephrin-B2. Blocking ephrin-B2 with scFv antibody fragments leads to inhibition of endothelial cell migration and tube formation in in vitro studies, which is in agreement with the observation that in xenografted mice this approach resulted in reduction in blood and lymphatic vessel density (Abengozar et al., 2012). Another potential target for blocking lymphangiogenesis is Nrp2. Anti-Nrp2 antibody that inhibits the binding of VEGF-C to Nrp2 and blocks the formation of the Nrp2-VEGFR-3 complex significantly suppresses LEC migration as well as tumor-dependent

${ }^{3}$ [online] access on 26.03.2013; www.circadian.com.au/sites/default/files/Circadian\%20partner\%20lmClone\%20Systems\%20demonstrates\%20VEG FR-3\%20antibody\%20improves\%20anti-tumour\%20effects\%20of\%20chemotherapy\%20in\%20mouse\%20tumour\%20models.pdf

${ }^{4}$ [online], access on 26.03.2013; www.businesswire.com/cgi-bin/mmg.cgi?eid=6250628\&lang=en 
lymphangiogenesis and lymph node metastasis (Caunt et al., 2008).

Although impressive progress has been made in identifying prolymphangiogenic factors as well as in generation of neutralizing mAbs with evident efficiency in preclinical studies, only two of these products entered Phase 1 clinical trials.

\section{CONCLUSIONS}

Although major progress has been made in the vascular biology and theories connecting lymphangiogenesis and angiogenesis with tumor progression and metastasis have been proposed, clinical solutions based on these findings usually show little or no therapeutic effect on cancers when antiangiogenic or antilymphangiogenic factors are used as single agents. Preclinical and clinical studies demonstrate that normalization of tumor blood vessels and inhibition of tumor-induced lymphatic formation with the use of antiangiogenic and antilymphangiogenic therapeutic monoclonal antibodies seems to be a valid direction in cancer treatment when combined with other antitumor agents. This strategy might improve the efficiency of chemotherapy, radiotherapy, and immunotherapy based on the ACT. As the molecular pathogenesis of cancers is a matter of extreme complexity, the changes leading to malignant transformation may involve both (i) extracellular and membrane-associated molecules (such as the growth factors and their receptors), and (ii) intracellular factors and effector molecules responsible for the metastatic properties of tumor cells.

An important issue, resulting directly from the abovedescribed diversity of mechanisms of malignancy, is the problem of proper patient selection for clinical trials. Only patients that, according to the current state of knowledge, can be cured using therapeutics acting on extracellular and membrane-associated targets, should be chosen. This demonstrates the need to find new molecular biomarkers that would ideally give an insight into the pathogenesis of each particular case of the malignant disease and help to assess the chances of recovery, to choose an appropriate therapy, and to monitor changes in the tumor throughout the treatment.

\section{Acknowledgements}

This work was supported by a grant from the PolishSwiss Research Programme (PSPB-057/2010 to JB).

\section{REFERENCES}

Abengozar MA, de Frutos S, Ferreiro S, Soriano J, Perez-Martinez M, Olmeda D, Marenchino M, Canamero M, Ortega S, Megias D, Rodriguez A, Martinez-Torrecuadrada JL (2012) Blocking ephrinB2 with highly specific antibodies inhibits angiogenesis, lymphangiogenesis, and tumor growth. Blood 119: 4565-4576.

Acevedo VD, Ittmann M, Spencer DM (2009) Paths of FGFR-driven tumorigenesis. Cell Cycle 8: 580-588.

Achen MG, Stacker SA (2006) Tumor lymphangiogenesis and metastatic spread-new players begin to emerge. Int J Cancer 119: 1755-1760.

Achen MG, Williams RA, Minekus MP, Thornton GE, Stenvers K, Rogers PA, Lederman F, Roufail S, Stacker SA (2001) Localization of vascular endothelial growth factor-D in malignant melanoma suggests a role in tumour angiogenesis. J Pathol 193: 147-154.

Agha CA, Ibrahim S, Hassan A, Elias DA, Fathallah-Shaykh HM (2010) Bevacizumab is active as a single agent against recurrent malignant gliomas. Anticancer Res 30: 609-611.

Alitalo K (2011) The lymphatic vasculature in disease. Nat Med 17: 1371-1380.

Alitalo K, Tammela T, Petrova TV (2005) Lymphangiogenesis in development and human disease. Nature 438: 946-953.

Amin DN, Hida K, Bielenberg DR, Klagsbrun M (2006) Tumor endothelial cells express epidermal growth factor receptor (EGFR) but not ErbB3 and are responsive to EGF and to EGFR kinase inhibitors. Cancer Res 66: 2173-2180.

Amin DN, Bielenberg DR, Lifshits E, Heymach JV, Klagsbrun M (2008) Targeting EGFR activity in blood vessels is sufficient to inhibit tumor growth and is accompanied by an increase in VEGFR-2 dependence in tumor endothelial cells. Microvasc Res 76: 15-22.

Banerji S, Ni J, Wang SX, Clasper S, Su J, Tammi R, Jones M, Jackson DG (1999) LYVE-1, a new homologue of the CD44 glycoprotein, is a lymph-specific receptor for hyaluronan. J Cell Biol 144: 789-801.

Berezhnaya NM (2010) Interaction between tumor and immune system: the role of tumor cell biology. Exp Oncol 32: 159-166.

Besse B, Tsao LC, Chao DT, Fang Y, Soria JC, Almokadem S, Belani CP (2013) Phase Ib safety and pharmacokinetic study of volociximab, an anti-alpha5beta1 integrin antibody, in combination with carboplatin and paclitaxel in advanced non-small-cell lung cancer. Ann Oncol 24: 90-96.

Bhaskar V, Fox M, Breinberg D, Wong MH, Wales PE, Rhodes S, DuBridge RB, Ramakrishnan V (2008) Volociximab, a chimeric integrin alpha5beta1 antibody, inhibits the growth of VX2 tumors in rabbits. Invest New Drugs 26: 7-12.

Bianco R, Garofalo S, Rosa R, Damiano V, Gelardi T, Daniele G, Marciano R, Ciardiello F, Tortora G (2008) Inhibition of mTOR pathway by everolimus cooperates with EGFR inhibitors in human tumours sensitive and resistant to anti-EGFR drugs. Br J Cancer 98: 923-930.

Boehm T, Folkman J, Browder T, O’Reilly MS (1997) Antiangiogenic therapy of experimental cancer does not induce acquired drug resistance. Nature 390: 404-407.

Bonner JA, Harari PM, Giralt J, Cohen RB, Jones CU, Sur RK, Raben D, Baselga J, Spencer SA, Zhu J, Youssoufian H, Rowinsky EK, Ang KK (2010) Radiotherapy plus cetuximab for locoregionally advanced head and neck cancer: 5-year survival data from a phase 3 randomised trial, and relation between cetuximab-induced rash and survival. Lancet Oncol 11: 21-28.

Borgstrom P, Bourdon MA, Hillan KJ, Sriramarao P, Ferrara N (1998) Neutralizing anti-vascular endothelial growth factor antibody completely inhibits angiogenesis and growth of human prostate carcinoma micro tumors in vivo. Prostate 35: 1-10.

Breiteneder-Geleff S, Soleiman A, Kowalski H, Horvat R, Amann G, Kriehuber E, Diem K, Weninger W, Tschachler E, Alitalo K, Kerjaschki D (1999) Angiosarcomas express mixed endothelial phenotypes of blood and lymphatic capillaries: podoplanin as a specific marker for lymphatic endothelium. Am I Pathol 154: 385-394.

Buchler P, Reber HA, Buchler M, Shrinkante S, Buchler MW, Friess H, Semenza GL, Hines OJ (2003) Hypoxia-inducible factor 1 regulates vascular endothelial growth factor expression in human pancreatic cancer. Pancreas 26: 56-64.

Burstein HJ, Chen YH, Parker LM, Savoie J, Younger J, Kuter I, Ryan PD, Garber JE, Chen H, Campos SM, Shulman LN, Harris LN, Gelman R, Winer EP (2008) VEGF as a marker for outcome among advanced breast cancer patients receiving anti-VEGF therapy with bevacizumab and vinorelbine chemotherapy. Clin Cancer Res 14: 7871-7877.

Bussolati B, Deambrosis I, Russo S, Deregibus MC, Camussi G (2003) Altered angiogenesis and survival in human tumor-derived endothelial cells. Faseb J 17: 1159-1161.

Casanovas O, Hicklin DJ, Bergers G, Hanahan D (2005) Drug resistance by evasion of antiangiogenic targeting of VEGF signaling in late-stage pancreatic islet tumors. Cancer Cell 8: 299-309.

Cascone T, Herynk MH, Xu L, Du Z, Kadara H, Nilsson MB, Oborn CJ, Park YY, Erez B, Jacoby JJ, Lee JS, Lin HY, Ciardiello F, Herbst RS, Langley RR, Heymach JV (2011) Upregulated stromal EGFR and vascular remodeling in mouse xenograft models of angiogenesis inhibitor-resistant human lung adenocarcinoma. J Clin Invest 121: 1313-1328.

Caunt M, Mak J, Liang WC, Stawicki S, Pan Q, Tong RK, Kowalski J, Ho C, Reslan HB, Ross J, Berry L, Kasman I, Zlot C, Cheng Z, Le Couter J, Filvaroff EH, Plowman G, Peale F, French D, Carano R, Koch AW, Wu Y, Watts RJ, Tessier-Lavigne M, Bagri A (2008) Blocking neuropilin-2 function inhibits tumor cell metastasis. Cancer Cell 13: 331-342.

Chamberlain MC (2011) Bevacizumab for the treatment of recurrent glioblastoma. Clin Med Insights Oncol 5: 117-129.

Chen JC, Chang YW, Hong CC, Yu YH, Su JL (2012) The Role of the VEGF-C/VEGFRs Axis in Tumor Progression and Therapy. Int $J$ Mol Sci 14: 88-107.

Chen Z, Varney ML, Backora MW, Cowan K, Solheim JC, Talmadge JE, Singh RK (2005) Down-regulation of vascular endothelial cell growth factor-C expression using small interfering RNA vectors in mammary tumors inhibits tumor lymphangiogenesis and spontaneous metastasis and enhances survival. Cancer Res 65: 9004-9011.

Chouaib S, Kieda C, Benlalam H, Noman MZ, Mami-Chouaib F, Ruegg C (2010) Endothelial cells as key determinants of the tumor microenvironment: interaction with tumor cells, extracellular matrix and immune killer cells. Crit Rev Immunol 30: 529-545. 
Christiansen A, Detmar M (2011) Lymphangiogenesis and cancer. Genes Cancer 2: 1146-1158.

Cianfarani F, Mastroeni S, Odorisio T, Passarelli F, Cattani C, Mannooranparampil TJ, Fortes C, Failla CM (2012) Expression of vascular endothelial growth factor-C in primary cutaneous melanoma predicts sentinel lymph node positivity. J Cutan Pathol 39: 826-834.

Ciardiello F, De Vita F, Orditura M, Tortora G (2004) The role of EGFR inhibitors in nonsmall cell lung cancer. Curr Opin Oncol 16: 130-135.

Ciardiello F, Bianco R, Damiano V, Fontanini G, Caputo R, Pomatico G, De Placido S, Bianco AR, Mendelsohn J, Tortora G (2000) Antiangiogenic and antitumor activity of anti- epidermal growth factor receptor C225 monoclonal antibody in combination with vascular endothelial growth factor antisense oligonucleotide in human GEO colon cancer cells. Clin Cancer Res 6: 3739-3747.

Conley SJ, Gheordunescu E, Kakarala P, Newman B, Korkaya H, Heath AN, Clouthier SG, Wicha MS (2012) Antiangiogenic agents increase breast cancer stem cells via the generation of tumor hypoxia. Proc Natl Acad Sci USA 109: 2784-2789.

Desselle A, Chaumette T, Gaugler MH, Cochonneau D, Fleurence J, Dubois N, Hulin P, Aubry J, Birkle S, Paris F (2012) Anti-Gb3 monoclonal antibody inhibits angiogenesis and tumor development. PLoS One 7: e45423.

Ding M, Fu X, Tan H, Wang R, Chen Z, Ding S (2012) The effect of vascular endothelial growth factor $\mathrm{C}$ expression in tumor-associated macrophages on lymphangiogenesis and lymphatic metastasis in breast cancer. Mol Med Rep 6: 1023-1029.

Dudley AC (2012) Tumor endothelial cells. Cold Spring Harb Perspect Med 2: a006536.

El-Sahwi K, Bellone S, Cocco E, Cargnelutti M, Casagrande F, Bellone M, Abu-Khalaf M, Buza N, Tavassoli FA, Hui P, Silasi DA, Azodi M, Schwartz PE, Rutherford TJ, Pecorelli S, Santin AD (2010) In vitro activity of pertuzumab in combination with trastuzumab in uterine serous papillary adenocarcinoma. Br J Cancer 102: 134-143.

Ellis LM (2004) Epidermal growth factor receptor in tumor angiogenesis. Hematol Oncol Clin North Am 18: 1007-1021, viii.

Faibish M, Francescone R, Bentley B, Yan W, Shao R (2011) A YKL40-neutralizing antibody blocks tumor angiogenesis and progression: a potential therapeutic agent in cancers. Mol Cancer Ther 10: 742-751.

Feng Y, Hu J, Ma J, Feng K, Zhang X, Yang S, Wang W, Zhang J, Zhang Y (2011) RNAi- mediated silencing of VEGF-C inhibits non-small cell lung cancer progression by simultaneously downregulating the CXCR4, CCR7, VEGFR-2 and VEGFR-3-dependent axes-induced ERK, p38 and AKT signalling pathways. Eur J Cancer 47: 2353-2363.

Ferrara N (2004) Vascular endothelial growth factor as a target for anticancer therapy. Oncologist 9 (Suppl 1): 2-10.

Ferrara N, Gerber HP (2001) The role of vascular endothelial growth factor in angiogenesis. Acta Haematol 106: 148-156.

Ferrara N, Gerber HP, LeCouter J (2003) The biology of VEGF and its receptors. Nat Med 9: 669-676.

Fischer C, Mazzone M, Jonckx B, Carmeliet P (2008) FLT1 and its ligands VEGFB and PlGF: drug targets for anti-angiogenic therapy? Nat Rev Cancer 8: 942-956.

Folkman J (1971) Tumor angiogenesis: therapeutic implications. N Engl J Med 285: 1182-1186.

Fox SB, Generali DG, Harris AL (2007) Breast tumour angiogenesis. Breast Cancer Res 9: 216.

Fukumura D, Xavier R, Sugiura T, Chen Y, Park EC, Lu N, Selig M, Nielsen G, Taksir T, Jain RK, Seed B (1998) Tumor induction of VEGF promoter activity in stromal cells. Cell 94: 715-725.

Gabrilovich D, Ishida T, Oyama T, Ran S, Kravtsov V, Nadaf S, Carbone DP (1998) Vascular endothelial growth factor inhibits the development of dendritic cells and dramatically affects the differentiation of multiple hematopoietic lineages in vivo. Blood 92: 4150-4166.

Gao P, Zhou GY, Zhang QH, Su ZX, Zhang TG, Xiang L, Wang Y, Zhang SL, Mu K (2009) Lymphangiogenesis in gastric carcinoma correlates with prognosis. J Pathol 218: 192-200.

Gerber DE, Gupta P, Dellinger MT, Toombs JE, Peyton M, Duignan I, Malaby J, Bailey T, Burns C, Brekken RA, Loizos N (2012) Stromal platelet-derived growth factor receptor alpha (PDGFRalpha) provides a therapeutic target independent of tumor cell PDGFRalpha expression in lung cancer xenografts. Mol Cancer Ther 11: 2473-2482.

Gerber HP, Ferrara N (2005) Pharmacology and pharmacodynamics of bevacizumab as monotherapy or in combination with cytotoxic therapy in preclinical studies. Cancer Res 65: 671-680.

Giantonio BJ, Catalano PJ, Meropol NJ, O'Dwyer PJ, Mitchell EP, Alberts SR, Schwartz MA, Benson AB, 3rd, Eastern Cooperative Oncology Group Study E (2007) Bevacizumab in combination with oxaliplatin, fluorouracil, and leucovorin (FOLFOX4) for previously treated metastatic colorectal cancer: results from the Eastern Cooperative Oncology Group Study E3200. J Clin Oncol 25: 1539-1544.

Goldman CK, Kim J, Wong WL, King V, Brock T, Gillespie GY (1993) Epidermal growth factor stimulates vascular endothelial growth factor production by human malignant glioma cells: a model of glioblastoma multiforme pathophysiology. Mol Biol Cell 4: 121133.

Gorski DH, Beckett MA, Jaskowiak NT, Calvin DP, Mauceri HJ, Salloum RM, Seetharam S, Koons A, Hari DM, Kufe DW, Weichselbaum RR (1999) Blockage of the vascular endothelial growth factor stress response increases the antitumor effects of ionizing radiation. Cancer Res 59: 3374-3378.

Gossage L, Eisen T (2010) Targeting multiple kinase pathways: a change in paradigm. Clin Cancer Res 16: 1973-1978.

Grepin R, Pages G (2010) Molecular mechanisms of resistance to tumour anti-angiogenic strategies. I Oncol 2010: 835-680.

Hajrasouliha AR, Funaki T, Sadrai Z, Hattori T, Chauhan SK, Dana R (2012) Vascular endothelial growth factor-C promotes alloimmunity by amplifying antigen-presenting cell maturation and lymphangiogenesis. Invest Ophthalmol Vis Sci 53: 1244-1250.

Hecht JR, Mitchell E, Chidiac T, Scroggin C, Hagenstad C, Spigel D, Marshall J, Cohn A, McCollum D, Stella P, Deeter R, Shahin S, Amado RG (2009) A randomized phase IIIB trial of chemotherapy, bevacizumab, and panitumumab compared with chemotherapy and bevacizumab alone for metastatic colorectal cancer. J Clin Oncol 27: 672-680.

Heun J, Holen K (2007) Treatment with panitumumab after a severe infusion reaction to cetuximab in a patient with metastatic colorectal cancer: a case report. Clin Colorectal Cancer 6: 529-531.

Holopainen T, Saharinen P, D'Amico G, Lampinen A, Eklund L, Sormunen R, Anisimov A, Zarkada G, Lohela M, Helotera H, Tammela T, Benjamin LE, Yla-Herttuala S, Leow CC, Koh GY, Alitalo $\mathrm{K}$ (2012) Effects of angiopoietin-2-blocking antibody on endothelial cell- cell junctions and lung metastasis. I Natl Cancer Inst 104: $461-475$

Hurwitz H, Fehrenbacher L, Novotny W, Cartwright T, Hainsworth J, Heim W, Berlin J, Baron A, Griffing S, Holmgren E, Ferrara N, Fyfe G, Rogers B, Ross R, Kabbinavar F (2004) Bevacizumab plus irinotecan, fluorouracil, and leucovorin for metastatic colorectal cancer. N Engl J Med 350: 2335-2342.

Ingvarsen S, Porse A, Erpicum C, Maertens L, Jurgensen HJ, Madsen DH, Melander MC, Gardsvoll H, Hoyer-Hansen G, Noel A, Holmbeck K, Engelholm LH, Behrendt N (2013) Targeting a single function of the multifunctional matrix metalloprotease MT1-MMP. Impact on lymphangiogenesis. J Biol Chem. ?

Issa A, Le TX, Shoushtari AN, Shields JD, Swartz MA (2009) Vascular endothelial growth factor-C and C-C chemokine receptor 7 in tumor cell-lymphatic cross-talk promote invasive phenotype. Cancer Res 69: 349-357.

Jain RK, Carmeliet PF (2001) Vessels of death or life. Sci Am 285: $38-45$.

Jimenez X, Lu D, Brennan L, Persaud K, Liu M, Miao H, Witte L, Zhu Z (2005) A recombinant, fully human, bispecific antibody neutralizes the biological activities mediated by both vascular endothelial growth factor receptors 2 and 3. Mol Cancer Ther 4: 427-434.

Jonker DJ, O'Callaghan CJ, Karapetis CS, Zalcberg JR, Tu D, Au HJ, Berry SR, Krahn M, Price T, Simes RJ, Tebbutt NC, van Hazel G, Wierzbicki R, Langer C, Moore MJ (2007) Cetuximab for the treatment of colorectal cancer. N Engl J Med 357: 2040-2048.

June CH (2007) Principles of adoptive T cell cancer therapy. J Clin Invest 117: 1204-1212. Kabbinavar F, Hurwitz HI, Fehrenbacher L, Meropol NJ, Novotny WF, Lieberman G, Griffing S, Bergsland E (2003) Phase II, randomized trial comparing bevacizumab plus fluorouracil (FU)/leucovorin ( $\mathrm{LV}$ ) with $\mathrm{FU} / \mathrm{LV}$ alone in patients with metastatic colorectal cancer. I Clin Oncol 21: 60-65.

Kandalaft LE, Powell Jr DJ, Chiang CL, Tanyi J, Kim S, Bosch M, Montone K, Mick R, Levine BL, Torigian DA, June CH, Coukos G (2013) Autologous lysate-pulsed dendritic cell vaccination followed by adoptive transfer of vaccine-primed ex vivo co-stimulated $\mathrm{T}$ cells in recurrent ovarian cancer. Oncoimmunology 2: e22664.

Karpanen T, Heckman CA, Keskitalo S, Jeltsch M, Ollila H, Neufeld G, Tamagnone L, Alitalo K (2006) Functional interaction of VEGF-C and VEGF-D with neuropilin receptors. FASEB J 20: 1462-1472.

Kashima K, Watanabe M, Satoh Y, Hata J, Ishii N, Aoki Y (2012) Inhibition of lymphatic metastasis in neuroblastoma by a novel neutralizing antibody to vascular endothelial growth factor-D. Cancer Sci 103: $2144-2152$.

Keating GM (2010) Panitumumab: a review of its use in metastatic colorectal cancer. Drugs 70: 1059-1078.

Kerbel RS (1991) Inhibition of tumor angiogenesis as a strategy to circumvent acquired resistance to anti-cancer therapeutic agents. Bioessays 13: 31-36.

Khan ST, Pixley RA, Liu Y, Bakdash N, Gordon B, Agelan A, Huang Y, Achary MP, Colman RW (2010) Inhibition of metastasis of syngeneic murine melanoma in vivo and vasculogenesis in vitro by monoclonal antibody C11C1 targeted to domain 5 of high molecular weight kininogen. Cancer Immunol Immunother 59: 1885-1893.

Kim KJ, Li B, Winer J, Armanini M, Gillett N, Phillips HS, Ferrara N (1993) Inhibition of vascular endothelial growth factor-induced angiogenesis suppresses tumour growth in vivo. Nature 362: 841-844. 
Kim YJ, Lee HJ, Kim TM, Eisinger-Mathason TS, Zhang AY, Schmidt B, Karl DL, Nakazawa MS, Park PJ, Simon MC, Yoon SS (2013) Overcoming evasive resistance from vascular endothelial growth factor a inhibition in sarcomas by genetic or pharmacologic targeting of hypoxia-inducible factor 1alpha. Int J Cancer 132: 29-41.

Krasnoperov V, Kumar SR, Ley E, Li X, Scehnet J, Liu R, Zozulya S, Gill PS (2010) Novel EphB4 monoclonal antibodies modulate angiogenesis and inhibit tumor growth. Am J Pathol 176: 2029-2038.

Laskin JJ, Sandler AB (2004) Epidermal growth factor receptor: a promising target in solid tumours. Cancer Treat Rev 30: 1-17.

Laskin JJ, Sandler AB (2004) Epidermal growth factor receptor inhibitors in lung cancer therapy. Semin Respir Crit Care Med 25 (Suppl 1): $17-27$.

Lee C, Raffaghello L, Longo VD (2012) Starvation, detoxification, and multidrug resistance in cancer therapy. Drug Resist Updat 15: 114 122.

Lee CG, Heijn M, di Tomaso E, Griffon-Etienne G, Ancukiewicz M, Koike C, Park KR, Ferrara N, Jain RK, Suit HD, Boucher Y (2000) Anti-Vascular endothelial growth factor treatment augments tumor radiation response under normoxic or hypoxic conditions. Cancer Res 60: 5565-5570.

Lee SH (2011) Tanibirumab (TTAC-0001): a fully human monoclonal antibody targets vascular endothelial growth factor receptor 2 (VEGFR-2). Arch Pharm Res 34: 1223-1226.

Leow CC, Coffman K, Inigo I, Breen S, Czapiga M, Soukharev S, Gingles N, Peterson N, Fazenbaker C, Woods R, Jallal B, Ricketts SA, Lavallee T, Coats S, Chang Y (2012) MEDI3617, a human anti-angiopoietin 2 monoclonal antibody, inhibits angiogenesis and tumor growth in human tumor xenograft models. Int I Oncol 40: 1321-1330.

Leppanen VM, Prota AE, Jeltsch M, Anisimov A, Kalkkinen N, Strandin T, Lankinen H, Goldman A, Ballmer-Hofer K, Alitalo K (2010) Structural determinants of growth factor binding and specificity by VEGF receptor 2. Proc Natl Acad Sci USA 107: 2425-2430.

Li B, Lalani AS, Harding TC, Luan B, Koprivnikar K, Huan Tu G, Prell R, VanRoey MJ, Simmons AD, Jooss K (2006) Vascular endothelial growth factor blockade reduces intratumoral regulatory $\mathrm{T}$ cells and enhances the efficacy of a GM-CSF-secreting cancer immunotherapy. Clin Cancer Res 12: 6808-6816.

Liersch R, Hirakawa S, Berdel WE, Mesters RM, Detmar M (2012) Induced lymphatic sinus hyperplasia in sentinel lymph nodes by VEGF-C as the earliest premetastatic indicator. Int J Oncol 41: 20732078.

Lieu C, Heymach J, Overman M, Tran H, Kopetz S (2011) Beyond VEGF: inhibition of the fibroblast growth factor pathway and antiangiogenesis. Clin Cancer Res 17: 6130-6139.

Loges S, Schmidt T, Carmeliet P (2010) Mechanisms of resistance to anti-angiogenic therapy and development of third-generation antiangiogenic drug candidates. Genes Cancer 1: 12-25.

Lund AW, Swartz MA (2010) Role of lymphatic vessels in tumor immunity: passive conduits or active participants? I Mammary Gland Biol Neoplasia 15: 341-352.

Lund AW, Duraes FV, Hirosue S, Raghavan VR, Nembrini C, Thomas SN, Issa A, Hugues S, Swartz MA (2012) VEGF-C promotes immune tolerance in B16 melanomas and cross-presentation of tumor antigen by lymph node lymphatics. Cell Rep 1: 191-199.

Luttun A, Tjwa M, Carmeliet P (2002) Placental growth factor (PlGF) and its receptor Flt-1 (VEGFR-1): novel therapeutic targets for angiogenic disorders. Ann N Y Acad Sci 979: 80-93.

Luttun A, Tjwa M, Moons L, Wu Y, Angelillo-Scherrer A, Liao F, Nagy JA, Hooper A, Priller J, De Klerck B, Compernolle V, Dací E, Bohlen P, Dewerchin M, Herbert JM, Fava R, Matthys P, Carmeliet G, Collen D, Dvorak HF, Hicklin DJ, Carmeliet P (2002) Revascularization of ischemic tissues by PlGF treatment, and inhibition of tumor angiogenesis, arthritis and atherosclerosis by anti-Flt1. Nat Med 8: 831-840.

Makinen T, Veikkola T, Mustjoki S, Karpanen T, Catimel B, Nice EC, Wise L, Mercer A, Kowalski H, Kerjaschki D, Stacker SA, Achen MG, Alitalo K (2001) Isolated lymphatic endothelial cells transduce growth, survival and migratory signals via the VEGF-C/D receptor VEGFR-3. EMBO I 20: 4762-4773.

Mandriota SJ, Jussila L, Jeltsch M, Compagni A, Baetens D, Prevo R, Banerji S, Huarte J, Montesano R, Jackson DG, Orci L, Alitalo K, Christofori G, Pepper MS (2001) Vascular endothelial growth factor-C-mediated lymphangiogenesis promotes tumour metastasis. EMBO J 20: 672-682.

Miller K, Wang M, Gralow J, Dickler M, Cobleigh M, Perez EA, Shenkier T, Cella D, Davidson NE (2007) Paclitaxel plus bevacizumab versus paclitaxel alone for metastatic breast cancer. $N$ Engl J Med 357: 2666-2676.

Mulligan JK, Day TA, Gillespie MB, Rosenzweig SA, Young MR (2009) Secretion of vascular endothelial growth factor by oral squamous cell carcinoma cells skews endothelial cells to suppress T-cell functions. Hum Immunol 70: 375-382.

O’Shaughnessy JA (2010) Lethal breast cancer. Clin Breast Cancer 10 Suppl 1: E6-7. Ocana A, Amir E, Vera F, Eisenhauer EA, Tannock
IF (2011) Addition of bevacizumab to chemotherapy for treatment of solid tumors: similar results but different conclusions. J Clin $\mathrm{On}$ col 29: 254-256.

Ohm JE, Carbone DP (2001) VEGF as a mediator of tumor-associated immunodeficiency. Immunol Res 23: 263-272.

Ohtsu A, Shah MA, Van Cutsem E, Rha SY, Sawaki A, Park SR, Lim HY, Yamada Y, Wu J, Langer B, Starnawski M, Kang YK (2011) Bevacizumab in combination with chemotherapy as first-line therapy in advanced gastric cancer: a randomized, double-blind, placebocontrolled phase III study. J Clin Oncol 29: 3968-3976.

Osada T, Chong G, Tansik R, Hong T, Spector N, Kumar R, Hurwitz HI, Dev I, Nixon AB, Lverly HK, Clay T, Morse MA (2008) The effect of anti-VEGF therapy on immature myeloid cell and dendritic cells in cancer patients. Cancer Immunol Immunother 57: 1115-1124.

Otrock ZK, Makarem JA, Shamseddine AI (2007) Vascular endothelial growth factor family of ligands and receptors: review. Blood Cells Mol Dis 38: 258-268.

Oyama T, Ran S, Ishida T, Nadaf S, Kerr L, Carbone DP, Gabrilovich DI (1998) Vascular endothelial growth factor affects dendritic cell maturation through the inhibition of nuclear factor-kappa B activation in hemopoietic progenitor cells. I Immunol 160: 1224-1232.

Patel DD, Goldberg RM (2006) Cetuximab-associated infusion reactions: pathology and management. Oncology (Williston Park) 20: 13731382; discussion 1382, 1392-1374, 1397.

Perrotte P, Matsumoto T, Inoue K, Kunivasu H, Eve BY, Hicklin DJ, Radinsky R, Dinney CP (1999) Anti-epidermal growth factor receptor antibody C225 inhibits angiogenesis in human transitional cell carcinoma growing orthotopically in nude mice. Clin Cancer Res 5: 257-265.

Persaud K, Tille JC, Liu M, Zhu Z, Jimenez X, Pereira DS, Miao HQ, Brennan LA, Witte L, Pepper MS, Pytowski B (2004) Involvement of the VEGF receptor 3 in tubular morphogenesis demonstrated with a human anti-human VEGFR-3 monoclonal antibody that antagonizes receptor activation by VEGF-C. J Cell Sci 117: 2745-2756.

Plate K (2001) From angiogenesis to lymphangiogenesis. Nat Med 7: 151-152.

Plate KH, Breier G, Weich HA, Mennel HD, Risau W (1994) Vascular endothelial growth factor and glioma angiogenesis: coordinate induction of VEGF receptors, distribution of VEGF protein and possible in vivo regulatory mechanisms. Int J Cancer 59: 520-529.

Poon RT, Fan ST, Wong J (2001) Clinical implications of circulating angiogenic factors in cancer patients. I Clin Oncol 19: 1207-1225.

Pytowski B, Goldman J, Persaud K, Wu Y, Witte L, Hicklin DJ, Skobe M, Boardman KC, Swartz MA (2005) Complete and specific inhibition of adult lymphatic regeneration by a novel VEGFR-3 neutralizing antibody. I Natl Cancer Inst 97: 14-21.

Ridgway J, Zhang G, Wu Y, Stawicki S, Liang WC, Chanthery Y, Kowalski J, Watts RJ, Callahan C, Kasman I, Singh M, Chien M, Tan C, Hongo JA, de Sauvage F, Plowman G, Yan M (2006) Inhibition of Dll4 signalling inhibits tumour growth by deregulating angiogenesis. Nature 444: 1083-1087.

Rinderknecht M, Villa A, Ballmer-Hofer K, Neri D, Detmar M (2010) Phage-derived fully human monoclonal antibody fragments to human vascular endothelial growth factor-C block its interaction with VEGF receptor-2 and 3. PLoS One 5: e11941.

Saltz LB, Lenz HJ, Kindler HL, Hochster HS, Wadler S, Hoff PM, Kemeny NE, Hollywood EM, Gonen M, Quinones M, Morse M, Chen HX (2007) Randomized phase II trial of cetuximab, bevacizumab, and irinotecan compared with cetuximab and bevacizumab alone in irinotecan-refractory colorectal cancer: the BOND-2 study. J Clin Oncol 25: 4557-4561.

Sato S, Drake AW, Tsuji I, Fan J (2012) A potent anti-HB-EGF monoclonal antibody inhibits cancer cell proliferation and multiple angiogenic activities of HB-EGF. PLoS One 7: e51964.

Schoppmann SF, Birner P, Stockl J, Kalt R, Ullrich R, Caucig C, Kriehuber E, Nagy K, Alitalo K, Kerjaschki D (2002) Tumor-associated macrophages express lymphatic endothelial growth factors and are related to peritumoral lymphangiogenesis. Am J Pathol 161: 947-956.

Shah GD, Loizos N, Youssoufian H, Schwartz JD, Rowinsky EK (2010) Rationale for the development of IMC-3G3, a fully human immunoglobulin $G$ subclass 1 monoclonal antibody targeting the platelet-derived growth factor receptor alpha. Cancer 116: 1018-1026.

Shen G, Huang H, Zhang A, Zhao T, Hu S, Cheng L, Liu J, Xiao W, Ling B, Wu Q, Song L, Wei W (2011) In vivo activity of novel anti-ErbB2 antibody chA21 alone and with Paclitaxel or Trastuzumab in breast and ovarian cancer xenograft models. Cancer Immunol Immunother 60: 339-348.

Shrimali RK, Yu Z, Theoret MR, Chinnasamy D, Restifo NP, Rosenberg SA (2010) Antiangiogenic agents can increase lymphocyte infiltration into tumor and enhance the effectiveness of adoptive immunotherapy of cancer. Cancer Res 70: 6171-6180.

Skobe M, Hawighorst T, Jackson DG, Prevo R, Janes L, Velasco P, Riccardi L, Alitalo K, Claffey K, Detmar M (2001) Induction of tumor lymphangiogenesis by VEGF-C promotes breast cancer metastasis. Nat Med 7: 192-198. 
Song JS, Sainz IM, Cosenza SC, Isordia-Salas I, Bior A, Bradford HN, Guo YL, Pixley RA, Reddy EP, Colman RW (2004) Inhibition of tumor angiogenesis in vivo by a monoclonal antibody targeted to domain 5 of high molecular weight kininogen. Blood 104: 2065-2072.

Stacker SA, Caesar C, Baldwin ME, Thornton GE, Williams RA, Prevo R, Jackson DG, Nishikawa S, Kubo H, Achen MG (2001) VEGF$\mathrm{D}$ promotes the metastatic spread of tumor cells via the lymphatics. Nat Med 7: 186-191.

Stewart KS, Zhou Z, Zweidler-McKay P, Kleinerman ES (2011) Deltalike ligand 4-Notch signaling regulates bone marrow-derived pericyte/vascular smooth muscle cell formation. Blood 117: 719-726.

Suzuki H, Onishi H, Wada J, Yamasaki A, Tanaka H, Nakano K, Morisaki T, Katano M (2010) VEGFR2 is selectively expressed by FOXP3high CD4+ Treg. Eur I Immunol 40: 197-203.

Tammela T, Zarkada G, Wallgard E, Murtomaki A, Suchting S, Wirzenius M, Waltari M, Hellstrom M, Schomber T, Peltonen R, Freitas C, Duarte A, Isoniemi H, Laakkonen P, Christofori G, Yla-Herttuala S, Shibuya M, Pytowski B, Eichmann A, Betsholtz C, Alitalo K (2008) Blocking VEGFR-3 suppresses angiogenic sprouting and vascular network formation. Nature 454: 656-660.

Thomas M, Kienast Y, Scheuer W, Bahner M, Kaluza K, Gassner C, Herting F, Brinkmann U, Seeber S, Kavlie A, Welschof M, Ries S, Weidner KM, Regula JT, Klein C (2013) A novel angiopoietin-2 selective fully human antibody with potent anti-tumoral and antiangiogenic efficacy and superior side effect profile compared to Pan-Angiopoietin-1/-2 inhibitors. PLoS One 8: e54923.

Tol J, Koopman M, Cats A, Rodenburg CJ, Creemers GJ, Schrama JG, Erdkamp FL, Vos AH, van Groeningen CJ, Sinnige HA, Richel DJ, Voest EE, Dijkstra JR, Vink-Borger ME, Antonini NF, Mol L, van Krieken JH, Dalesio O, Punt CJ (2009) Chemotherapy, bevacizumab, and cetuximab in metastatic colorectal cancer. $N$ Engl J Med 360: $563-572$.

Tvorogov D, Anisimov A, Zheng W, Leppanen VM, Tammela T, Laurinavicius S, Holnthoner W, Helotera H, Holopainen T, Jeltsch M, Kalkkinen N, Lankinen H, Ojala PM, Alitalo K (2010) Effective suppression of vascular network formation by combination of antibodies blocking VEGFR ligand binding and receptor dimerization. Cancer Cell 18: 630-640.

Viloria-Petit A, Crombet T, Jothy S, Hicklin D, Bohlen P, Schlaeppi JM, Rak J, Kerbel RS (2001) Acquired resistance to the antitumor effect of epidermal growth factor receptor-blocking antibodies in vivo: a role for altered tumor angiogenesis. Cancer Res 61: 50905101.

Wang F, Li HM, Wang HP, Ma JL, Chen XF, Wei F, Yi MY, Huang Q (2010) siRNA- mediated knockdown of VEGF-A, VEGF-C and
VEGFR-3 suppresses the growth and metastasis of mouse bladder carcinoma in vivo. Exp Ther Med 1: 899-904.

Warren RS, Yuan H, Matli MR, Gillett NA, Ferrara N (1995) Regulation by vascular endothelial growth factor of human colon cancer tumorigenesis in a mouse model of experimental liver metastasis. $J$ Clin Invest 95: 1789-1797.

Wigle JT, Oliver G (1999) Prox1 function is required for the development of the murine lymphatic system. Cell 98: 769-778.

Wu X, Fan Z, Masui H, Rosen N, Mendelsohn J (1995) Apoptosis induced by an anti-epidermal growth factor receptor monoclonal antibody in a human colorectal carcinoma cell line and its delay by insulin. J Clin Invest 95: 1897-1905.

Wu Y, Zhong Z, Huber J, Bassi R, Finnerty B, Corcoran E, Li H, Navarro E, Balderes P, Jimenez X, Koo H, Mangalampalli VR, Ludwig DL, Tonra JR, Hicklin DJ (2006) Anti-vascular endothelial growth factor receptor-1 antagonist antibody as a therapeutic agent for cancer. Clin Cancer Res 12: 6573-6584.

Wu Y, Cain-Hom C, Choy L, Hagenbeek TJ, de Leon GP, Chen Y, Finkle D, Venook R, Wu X, Ridgway J, Schahin-Reed D, Dow GJ, Shelton A, Stawicki S, Watts RJ, Zhang J, Choy R, Howard P, Kadyk L, Yan M, Zha J, Callahan CA, Hymowitz SG, Siebel CW (2010) Therapeutic antibody targeting of individual Notch receptors. Nature 464: 1052-1057.

Xu Y, Yuan L, Mak J, Pardanaud L, Caunt M, Kasman I, Larrivee B, Del Toro R, Suchting S, Medvinsky A, Silva J, Yang J, Thomas JL, Koch AW, Alitalo K, Eichmann A, Bagri A (2010) Neuropilin-2 mediates VEGF-C-induced lymphatic sprouting together with VEGFR3. J Cell Biol 188: 115-130.

Yarden Y (2001) The EGFR family and its ligands in human cancer. signalling mechanisms and therapeutic opportunities. Eur J Cancer 37 (Suppl 4): S3-S8.

You WK, McDonald DM (2008) The hepatocyte growth factor/c-Met signaling pathway as a therapeutic target to inhibit angiogenesis. $B M B$ Rep 41: 833-839.

Zhou H, Zha Z, Liu Y, Zhang H, Zhu J, Hu S, Shen G, Cheng L, Niu L, Greene MI, Teng M, Liu J (2011) Structural insights into the down-regulation of overexpressed $\mathrm{p} 185$ (her $2 / \mathrm{neu})$ protein of transformed cells by the antibody chA21. J Biol Chem 286: 31676-31683.

Zhu Z, Hattori K, Zhang H, Jimenez X, Ludwig DL, Dias S, Kussie P, Koo H, Kim HJ, Lu D, Liu M, Tejada R, Friedrich M, Bohlen P, Witte L, Rafii S (2003) Inhibition of human leukemia in an animal model with human antibodies directed against vascular endothelial growth factor receptor 2. Correlation between antibody affinity and biological activity. Leukemia 17: 604-611. 